\title{
REVIEW
}

\section{Lymphoedema After Breast Cancer Treatment is Associated With Higher Body Mass Index: A Systematic Review and Meta-Analysis}

\author{
Astère Manirakiza, ${ }^{a, b}$ Laurent Irakoze,${ }^{c}$ Lin Shui, ${ }^{d}$ Sébastien Manirakiza, ${ }^{e, f}$ Louis Ngendahayo ${ }^{e, g}$ \\ aDepartment of Oncology, Karuzi Fiftieth Hospital, Karuzi, Burundi; ${ }^{\circ}$ Department of Oncology, University Hospital Centre of Kamenge, Bujumbura, Burundi; \\ 'Department of Endocrinology, First Affiliated Hospital, Chongqing Medical University, Chongqing, China; ${ }^{\mathrm{D} D e p a r t m e n t ~ o f ~ O n c o l o g y, ~ W e s t ~ C h i n a ~ M e d i c a l ~ C e n t e r, ~}$ \\ Sichuan University, Chengdu, China; eFaculty of Medicine, University of Burundi, Bujumbura, Burundi; 'Department of Radiology, University Hospital Centre of \\ Kamenge, Bujumbura, Burundi; 9Department of Pathology, University Hospital Centre of Kamenge, Bujumbura, Burundi \\ Correspondence to Astère Manirakiza (asteremanirakiza@yahoo.fr)
}

\section{ABSTRACT}

Background: Excess body weight has been identified as an important risk factor for lymphoedema following breast cancer treatment, however it remains unclear how much risk increases as weight increases. We conducted a meta-analysis to assess the relationship between body mass index (BMI) and risk of lymphoedema in breast cancer patients, and to estimate the level of risk by $\mathrm{BMl}$ category.

Methods: We conducted a systematic search of all articles published through May 2018 in PubMed and the Cochrane library. Studies that included data on BMI and lymphoedema in breast cancer patients were included in the meta-analysis. We compared risk of lymphoedema in $B M l$ groups as: $B M l<25$ versus $B M l \geq 25, B M l<25$ versus $B M l \geq 30, B M I \geq 25$ to $<30$ versus $B M I \geq 30, B M l<30$ versus $B M l \geq 30, B M l<25$ versus $B M I \geq 25$ to $B M I<30$.

Results: After exclusion of ineligible studies, 57 studies were included in the meta-analysis. The mean difference in BMI between patients with lymphoedema compared to those without lymphoedema was $1.7(95 \% \mathrm{Cl}, 1.3-2.2)$. Compared to patients with a $\mathrm{BMl}<25$, risk of lymphoedema was higher in those with a $\mathrm{BMl}>25$ to $<30$ (odds ratio [OR] 1.3; $95 \% \mathrm{Cl}, 1.2$ to 1.5), a BMl $\geq 25$ (OR 1.7; $95 \% \mathrm{Cl}, 1.5$ to 1.9), or a $\mathrm{BMl} \geq 30$ (OR 1.9; $95 \% \mathrm{Cl}, 1.6$ to 2.4). Compared to patients with a $\mathrm{BMI}$ of $>25$ to $<30$, risk of lymphoedema was higher in patients with a BMl>30 (OR $1.5 ; 95 \% \mathrm{Cl}, 1.4$ to 1.8$)$.

Conclusion: Excess body weight is a risk factor for lymphoedema following treatment of breast cancer, with the magnitude of risk increasing across higher categories of BMI.

\section{INTRODUCTION}

L ymphoedema of the upper limb is a complication of breast cancer treatment, especially mastectomy, radiation therapy and chemotherapy. ${ }^{1}$ It results from reduced lymphatic drainage and stasis of fluid in the extremities, ${ }^{2}$ and can occur during treatment or develop years after treatment has been completed. ${ }^{3}$ Estimates of the prevalence of lymphoedema following breast cancer treatment are imprecise due to inconsistencies in the definition of lymphoedema..$^{4-8}$ However, 1 systematic review found that more than 1 in 5 women who survive breast cancer developed lymphoedema. ${ }^{9}$ Several clinical factors have been associated with increased risk of lymphoedema, including: breast surgery, axillary lymph node dissection, sentinel lymph node dissection, radiation therapy, and postoperative infections. ${ }^{10,11}$ Obesity has been identified as the primary demographic factor associated with increased risk of lymphoedema of the upper limb following breast cancer treatment.

A number of studies have examined the relationship between obesity and development of arm lymphoedema after breast cancer treatment, with the majority finding that. However, most studies do not report on the frequency of lymphoedema within strata of women who are normal weight, overweight or obese, thus precise estimates on the level of risk associated with each weight strata are lacking. Given the high frequency of overweight and obesity among breast cancer patients, clarification of the level of risk of lymphoedema after breast cancer treatment in overweight or obese women is needed to enhance clinical management of breast cancer in this patient subgroup.

We sought to address this knowledge gap by conducting meta-analyses to assess 1) whether body mass index (BMI, defined as weight in kilograms divided by 


\section{FIGURE 1. PRISMA Flow Diagram}

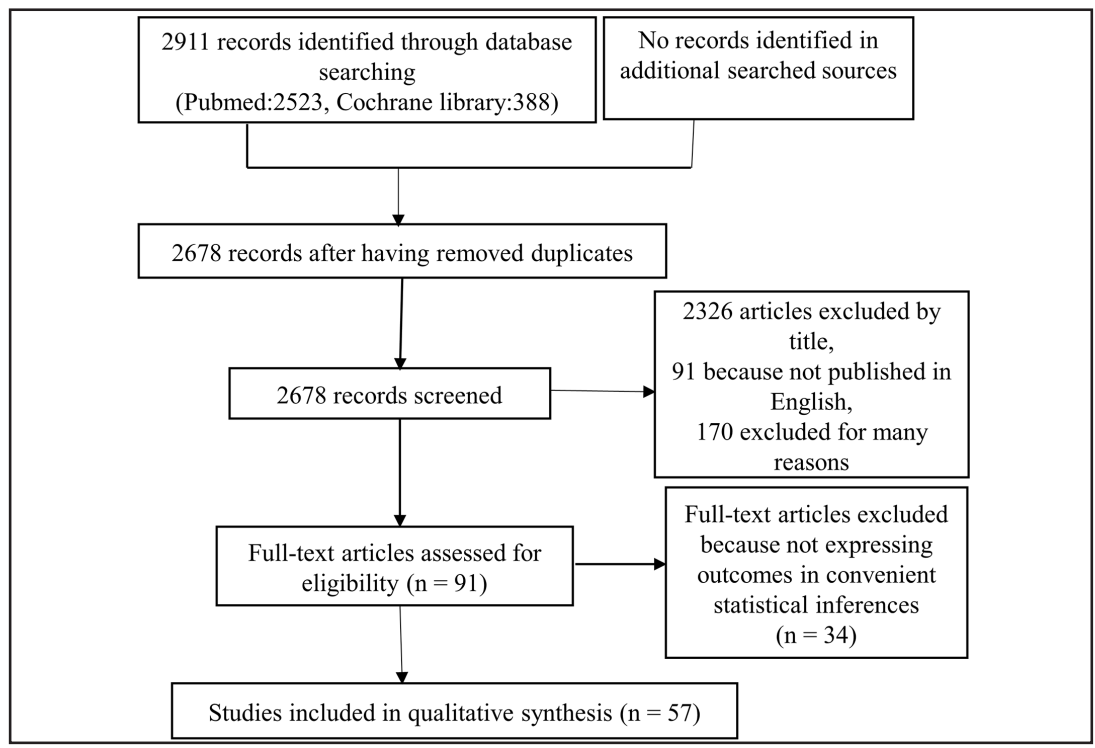

height in metres squared) differs in breast cancer patients with and without lymphoedema after breast cancer treatment, and 2) risk of lymphoedema after breast cancer treatment in subgroups of BMI.

\section{METHODS}

\section{Search Strategy}

A systematic search of all articles published in the English language up to 23 May 2018 was conducted on PubMed and the Cochrane library, using MeSH key words: "breast cancer and lymphoedema". All references resulting from the MeSH search were imported into Endnote X8, and were examined by 2 independent reviewers. During their first round of review, each reviewer evaluated study titles; those that did not contain the targeted search terms were excluded. During the second round of review the full-text of retained study were evaluated to determine if it was potentially eligible for inclusion in the meta-analyses. Discrepancies between reviewers were resolved via discussion.

\section{Inclusion and Exclusion Criteria}

The inclusion criteria were: publication in English in a peer-reviewed science or medical journal; assessment of BMI (as a continuous or categorical variable) and lymphoedema in female breast cancer patients; and a period of follow-up less than or equal to 10 years. No published abstracts were included. Included and excluded studies are summarised in Figure 1.

\section{Data Extraction}

The following variables were extracted from the published papers (Table): authors, year of publication, study design, patients, type of data, duration of the study, proportion of lymphoedema, lymphoedema evaluation, country where the study was conducted and the definition of lymphoedema. Where available, we extracted patient BMI as a continuous variable; means and ranges were adjusted into mean and standard deviation using the method described by Wan X. ${ }^{12}$ Data on BMI were also extracted as a categorical variable, and where appropriate, regrouped to represent the following categories: $\mathrm{BMI}<25, \mathrm{BMI} \geq 25, \mathrm{BMI} \geq 25$ to $<30$, and $\mathrm{BMI} \geq 30$.

\section{Quality Assessment of Studies}

We performed quality assessment of studies included in this meta-analysis using 2 tools: the Quality Assessment Tool for Observational Cohort and Cross-Sectional Studies, a 14item inventory; and the Quality Assessment of Case-Control Studies, a 12 -item inventory. ${ }^{13}$ If an observational cohort or cross-sectional study had more than 8 positive items, or a case-control study had more than 7 positive items, the study was deemed to be of high quality.

\section{Statistical Analysis}

In studies with continuous data for BMI, we calculated the mean difference and $95 \%$ confidence interval of BMI between patients with lymphoedema and those without lymphoedema. We used data on the number of lymphoedema events among patients within each BMI category to calculate odd ratios of the association between BMI category and lymph- 
TABLE. Characteristics of Studies Included in the Analysis

Authors Year Design

Patients

Duration PL $\begin{gathered}\text { Lymphoedema } \\ \text { Evaluation }\end{gathered}$ Country

Lymphoedema Definition

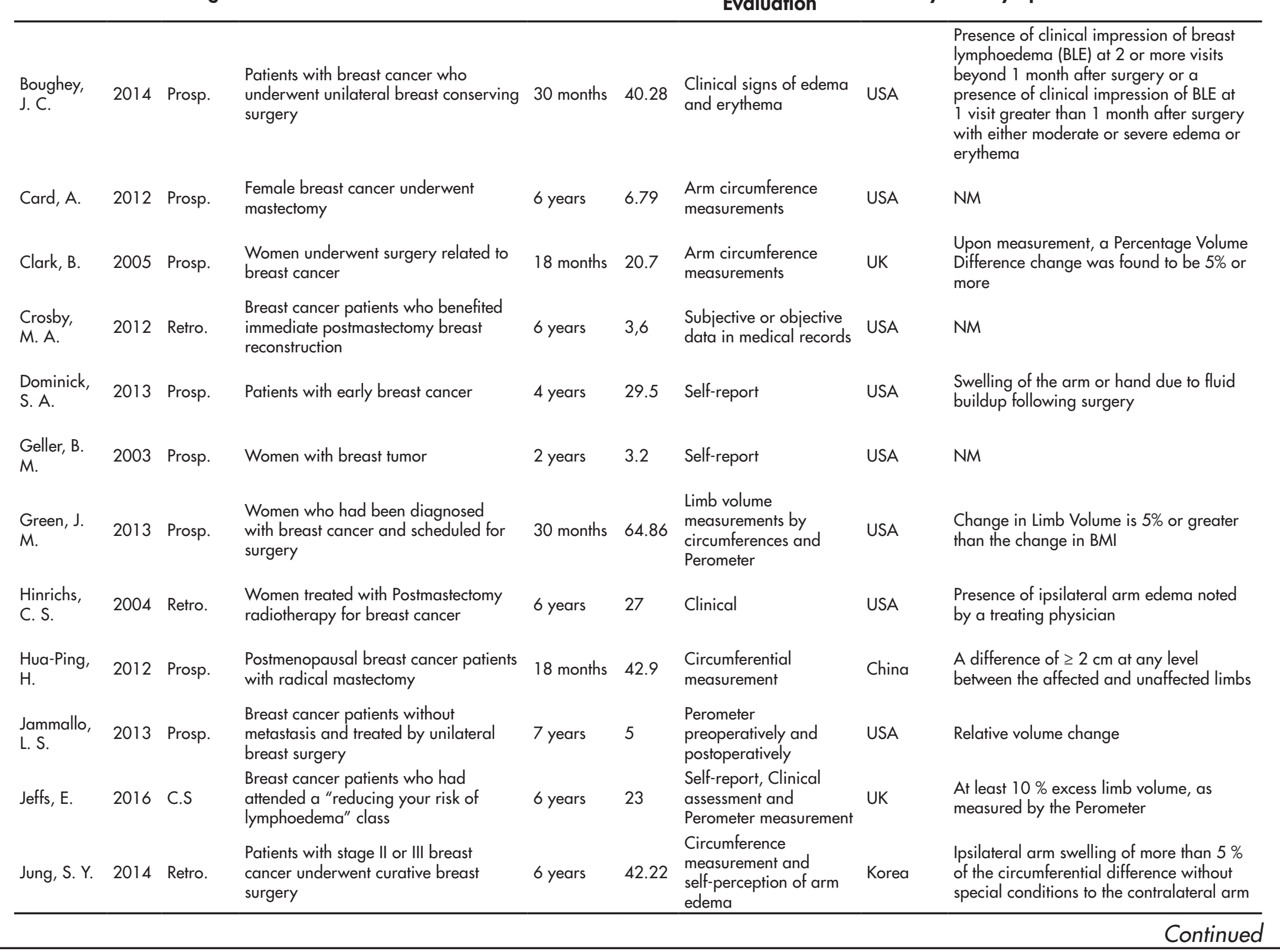


TABLE. Continued

\begin{tabular}{|c|c|c|c|c|c|c|c|c|}
\hline Authors & Year & Design & Patiens & Duration & PL & $\begin{array}{l}\text { Lymphoedema } \\
\text { Evaluation }\end{array}$ & Country & Lymphoedema Definition \\
\hline Kim, M. & 2015 & Retro. & $\begin{array}{l}\text { Clinically node-positive breast cancer } \\
\text { patients who underwent Neoadjuvant } \\
\text { chemotherapy followed by modified } \\
\text { radical mastectomy or BCS with } \\
\text { ALND and radiation therapy }\end{array}$ & 6 years & 42 & $\begin{array}{l}\text { Circumference } \\
\text { measurement and } \\
\text { patient perception of } \\
\text { arm edema }\end{array}$ & Korea & $\begin{array}{l}\text { Difference of } 5 \%-10 \% \text { in arm } \\
\text { measurement or only self-perception } \\
\text { of arm swelling with less than a } 5 \% \\
\text { measurement difference }\end{array}$ \\
\hline Kim, M. & 2016 & Retro. & $\begin{array}{l}\text { Breast cancer patients who } \\
\text { underwent curative breast surgery }\end{array}$ & 6 years & 34.5 & $\begin{array}{l}\text { Circumference } \\
\text { measurement and } \\
\text { patient perception of } \\
\text { arm edema }\end{array}$ & Korea & $\begin{array}{l}\text { Ipsilateral arm swelling of more than } \\
5 \% \text { of the circumferential difference } \\
\text { without special conditions to the } \\
\text { contralateral arm }\end{array}$ \\
\hline Kim, M. & 2013 & Retro. & $\begin{array}{l}\text { Patients who underwent primary } \\
\text { surgery with ALND excluded those } \\
\text { received neoadjuvant therapy } \\
\text { followed by surgery }\end{array}$ & 6 years & 17 & $\begin{array}{l}\text { Circumference } \\
\text { measurement and } \\
\text { patient perception of } \\
\text { arm edema }\end{array}$ & Korea & $\begin{array}{l}\text { Ipsilateral arm swelling of more than } \\
5 \% \text { of the circumferential difference } \\
\text { without special conditions to the } \\
\text { contralateral arm }\end{array}$ \\
\hline Kwan, M. L. & 2010 & Prosp. & $\begin{array}{l}\text { Patients with primary invasive breast } \\
\text { cancer }\end{array}$ & 22 months & 13.3 & $\begin{array}{l}\text { Electronic medical } \\
\text { records }\end{array}$ & USA & Disease codes \\
\hline Kwan, M. L. & 2016 & Prosp. & $\begin{array}{l}\text { Women newly diagnosed invasive } \\
\text { breast cancer }\end{array}$ & 101 moths & 11.6 & Self-report & USA & $\begin{array}{l}\text { Any event self-reported by the } \\
\text { participant that was } \geq 6 \text { months after } \\
\text { the breast cancer diagnosis }\end{array}$ \\
\hline Lee, S. H. & 2012 & Prosp. & Breast cancer survivors & 2 years & 60.42 & Arm circumference. & Korea & $\begin{array}{l}\text { Increase in arm circumference at any } \\
\text { level by } 2 \mathrm{~cm} \text { or more compared to the } \\
\text { contralateral side }\end{array}$ \\
\hline $\begin{array}{l}\text { Mahamaneerat, } \\
\text { W. K. }\end{array}$ & 2008 & Prosp. & $\begin{array}{l}\text { Postoperative unilateral breast } \\
\text { cancer survivors }\end{array}$ & 30 months & 19.17 & $\begin{array}{l}\text { Arm circumferences } \\
\text { and limb volume using } \\
\text { cylinder volume }\end{array}$ & USA & $\begin{array}{l}\text { Limb Volume increase of at least } 5 \% \\
\text { greater than BMI change during at least } \\
1 \text { visit after the postoperative visit }\end{array}$ \\
\hline Mak, S. S. & 2009 & C.C. & $\begin{array}{l}\text { Patients who underwent axillary } \\
\text { dissection for breast cancer }\end{array}$ & NM & 50 & $\begin{array}{l}\text { History and arm } \\
\text { circumference }\end{array}$ & China & $\begin{array}{l}\text { The contralateral arm circumference at } \\
\text { corresponding as reference }\end{array}$ \\
\hline Meeske, K. A. & 2009 & C.C & $\begin{array}{l}\text { Patients diagnosed in situ to Stage } \\
\text { III-A primary breast cancer }\end{array}$ & 18 months & 24 & Self-reported & USA & $\begin{array}{l}\text { Swelling due to an accumulation of } \\
\text { fluid in their arm, not to be confused } \\
\text { with swelling that occurs after surgery }\end{array}$ \\
\hline Menezes, M. M. & 2016 & Prosp. & $\begin{array}{l}\text { Patients treated by mastectomy with } \\
\text { axillary lymphadenectomy }\end{array}$ & 1 year & 33 & $\begin{array}{l}\text { Clinical and arm } \\
\text { circumference } \\
\text { measurement }\end{array}$ & Brazil & $\begin{array}{l}\text { Difference }>200 \mathrm{ml} \text { between the } \\
\text { volume of the affected limb and the } \\
\text { contralateral limb }\end{array}$ \\
\hline Monleon, S. & 2015 & Retro. & $\begin{array}{l}\text { Patients diagnosed primary invasive } \\
\text { breast cancer and treated by } \\
\text { surgically }\end{array}$ & 5 years & 33.4 & $\begin{array}{l}\text { Upper limb } \\
\text { circumference } \\
\text { measurement }\end{array}$ & Spain & $\begin{array}{l}\text { Difference of } 2 \mathrm{~cm} \text { or more at any } \\
\text { circumference point }\end{array}$ \\
\hline Morcos, B. & 2014 & C.S. & $\begin{array}{l}\text { Patients with breast carcinoma and } \\
\text { treated by surgery at least } 6 \text { months } \\
\text { prior to accrual }\end{array}$ & 6 years & 21.4 & $\begin{array}{l}\text { Measurement of the } \\
\text { mid-arm and forearm } \\
\text { circumference }\end{array}$ & Jordan & $\begin{array}{l}\text { Mid-arm or forearm circumference } \\
\text { difference between both limbs of } \geq 2 \mathrm{~cm}\end{array}$ \\
\hline
\end{tabular}


TABLE. Continued

\begin{tabular}{|c|c|c|c|c|c|c|c|c|}
\hline Authors & Year & Design & Patients & Duration & PL & $\begin{array}{l}\text { Lymphoedema } \\
\text { Evaluation }\end{array}$ & Country & Lymphoedema Definition \\
\hline $\begin{array}{l}\text { Norman, } \\
\text { S. A. }\end{array}$ & 2010 & Prosp. & $\begin{array}{l}\text { Patients with histologically confirmed } \\
\text { breast cancer }\end{array}$ & 6 years & 37.7 & $\begin{array}{l}\text { Questionnaire and } \\
\text { scoring system to assess } \\
\text { lymphoedema }\end{array}$ & USA & $\begin{array}{l}\text { Patient's perceived differences in the size } \\
\text { of her hands and arms }\end{array}$ \\
\hline $\begin{array}{l}\text { Ozaslan, } \\
\text { C. }\end{array}$ & 2004 & Prosp. & $\begin{array}{l}\text { Patients treated by modified radical } \\
\text { mastectomy with complete axillary } \\
\text { dissection }\end{array}$ & 30 months & 28 & $\begin{array}{l}\text { Arm circumference } \\
\text { measurement }\end{array}$ & Turkey & $\begin{array}{l}\text { Difference at any level compared with the } \\
\text { opposite upper extremity } \geq 2 \mathrm{~cm}\end{array}$ \\
\hline Park, J. H. & 2008 & Prosp. & $\begin{array}{l}\text { Women operated on by the same } \\
\text { surgeon in each hospital }\end{array}$ & 8 months & 24.9 & $\begin{array}{l}\text { Arm circumference } \\
\text { measurement }\end{array}$ & Korea & $\begin{array}{l}\text { Difference of } 2 \mathrm{~cm} \text { or more at any level } \\
\text { compared with the opposite upper } \\
\text { extremity }\end{array}$ \\
\hline Pinto, $M$. & 2013 & C.S. & $\begin{array}{l}\text { Patients who underwent mastectomy or } \\
\text { breast conserving } \\
\text { surgery with unilateral ALND }\end{array}$ & 5 months & 50 & Self-report & Italy & $\begin{array}{l}\text { Based on consensus document of the } \\
\text { International Society of Lymphology }\end{array}$ \\
\hline $\begin{array}{l}\text { Rebegea, } \\
\text { L. }\end{array}$ & 2015 & Prosp. & $\begin{array}{l}\text { Patients with breast cancer + any } \\
\text { treatment }\end{array}$ & 3 years & 5.9 & NM & Romania & NM \\
\hline $\begin{array}{l}\text { Ribeiro } \\
\text { Pereira, A. } \\
\text { C. P. }\end{array}$ & 2017 & Prosp. & $\begin{array}{l}\text { Women underwent ALND for breast } \\
\text { cancer }\end{array}$ & 16 months & 13.5 & $\begin{array}{l}\text { Circumference } \\
\text { measurement }\end{array}$ & Brazil & Difference of $200 \mathrm{ml}$ between the arms \\
\hline $\begin{array}{l}\text { Ridner, S. } \\
\text { H. }\end{array}$ & 2011 & Prosp. & $\begin{array}{l}\text { Women newly diagnosed breast } \\
\text { cancer survivors }\end{array}$ & 30 months & 19.6 & Using Perometer & USA & $\begin{array}{l}200 \mathrm{ml} \text { or } 10 \% \text { increase in arm volume } \\
\text { occurring on the side where breast } \\
\text { cancer treatment }\end{array}$ \\
\hline Soyder, A. & 2014 & Retro. & $\begin{array}{l}\text { Female patients with } 1 \text {-sided breast } \\
\text { cancer who had surgical intervention } \\
\text { to the breast and axilla }\end{array}$ & 15 months & 6.9 & $\begin{array}{l}\text { Arm circumferential } \\
\text { measurements }\end{array}$ & Turkey & $\begin{array}{l}\text { Difference of more than } 2 \mathrm{~cm} \text { in the } \\
\text { measurements made at the } 4 \text { regions } \\
\text { compared to the healthy side }\end{array}$ \\
\hline Stout, N. L. & 2011 & Prosp. & $\begin{array}{l}\text { Women with early-stage unilateral } \\
\text { breast cancer }\end{array}$ & 12 months & 50 & $\begin{array}{l}\text { Volume and girth } \\
\text { measurement by } \\
\text { Perometer + self-report }\end{array}$ & USA & $\begin{array}{l}3 \% \text { volume increase of the affected limb } \\
\text { from the preoperative measurement and } \\
\text { with consideration for the contralateral } \\
\text { limb }\end{array}$ \\
\hline $\begin{array}{l}\text { Swenson, } \\
\text { K. K. }\end{array}$ & 2009 & C.C. & $\begin{array}{l}\text { Patients clinically diagnosed of } \\
\text { lymphoedema and unilateral axillary } \\
\text { surgery for invasive breast cancer }\end{array}$ & 44 months & 50 & $\begin{array}{l}\text { Measure of Arm } \\
\text { Symptom Survey }\end{array}$ & USA & $\begin{array}{l}\text { Having patients rate them on a 5-point } \\
\text { Likert scale from } 1 \text { (no swelling) to } 5 \\
\text { (very severe swelling }\end{array}$ \\
\hline Togawa, K. & 2014 & Prosp. & $\begin{array}{l}\text { Women with first primary in situ or } \\
\text { stage I-III invasive breast cancer }\end{array}$ & 5 years & 29 & Self-report & USA & $\begin{array}{l}\text { Arm on the side of breast cancer swollen } \\
\text { because of accumulation of fluid in the } \\
\text { arm }\end{array}$ \\
\hline $\begin{array}{l}\text { Vieira, } \mathrm{R} \text {. } \\
\text { A. }\end{array}$ & 2016 & Retro. & Women with breast cancer & 3 years & 7.2 & Medical records & Brazil & Description in the medical records \\
\hline Wang, L. & 2016 & Prosp. & $\begin{array}{l}\text { Patients who had been diagnosed } \\
\text { with breast cancer and underwent } \\
\text { ALND }\end{array}$ & $\begin{array}{l}12 \\
\text { months }\end{array}$ & 31.84 & $\begin{array}{l}\text { Circumferential } \\
\text { measurement }\end{array}$ & China & $\begin{array}{l}\text { Difference of } 2 \mathrm{~cm} \text { or more at any } \\
\text { level compared with the opposite } \\
\text { upper extremity }\end{array}$ \\
\hline
\end{tabular}


TABLE. Continued

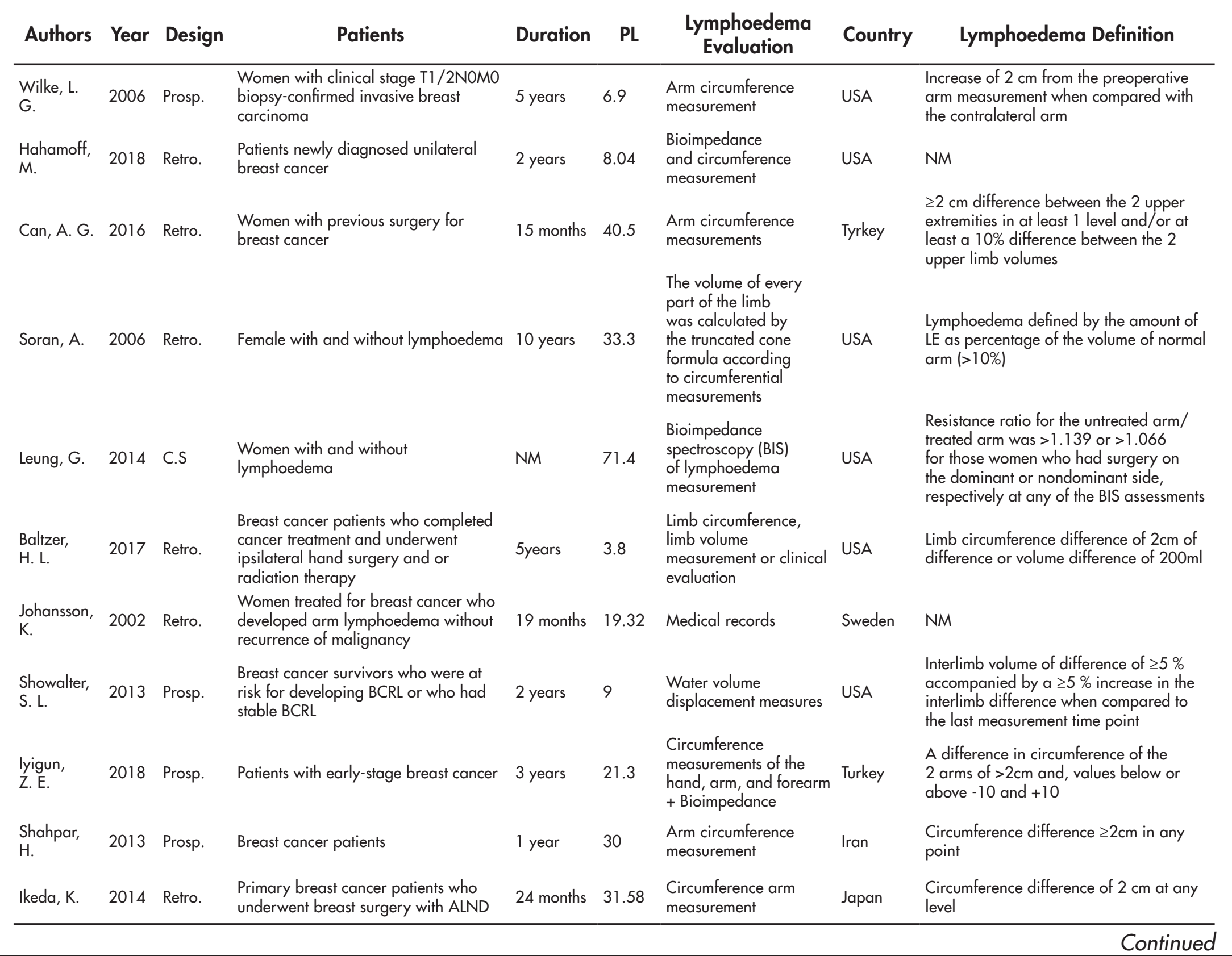


TABLE. Continued

\begin{tabular}{|c|c|c|c|c|c|c|c|c|}
\hline Authors & Year & Design & Patients & Duration & PL & $\begin{array}{l}\text { Lymphoedema } \\
\text { Evaluation }\end{array}$ & Country & Lymphoedema Definition \\
\hline $\begin{array}{l}\text { Kilbreath, } \\
\text { S. L. }\end{array}$ & 2013 & Prosp. & Women with early breast cancer & 12 months & 9.1 & $\begin{array}{l}\text { Circumference } \\
\text { measurement and } \\
\text { Bioimpedance } \\
\text { spectroscopy }\end{array}$ & Australia & $\begin{array}{l}\text { A ratio } \geq 1.139 \text { for women in whom the } \\
\text { surgery was on their dominant side and } \\
\text { a ratio } \geq 1.066 \text { for those in whom the } \\
\text { surgery was on the nondominant side }\end{array}$ \\
\hline Smoot, B. & 2014 & C.S. & $\begin{array}{l}\text { Unilateral breast cancer patients who } \\
\text { underwent surgery }\end{array}$ & NM & 47.37 & $\begin{array}{l}\text { Bioimpedance } \\
\text { spectroscopy + volume } \\
\text { of a truncated cone }\end{array}$ & USA & $\begin{array}{l}\text { Low frequency and } 200 \mathrm{ml} \text { difference } \\
\text { between the affected and unaffected } \\
\text { limbs }\end{array}$ \\
\hline Smoot, B. & 2010 & C.S. & $\begin{array}{l}\text { Women, with and without } \\
\text { lymphoedema, who had completed } \\
\text { active breast cancer treatment }\end{array}$ & NM & 50.69 & $\begin{array}{l}\text { Circumferential } \\
\text { assessment }+ \\
\text { Bioimpedance }\end{array}$ & USA & NM \\
\hline $\begin{array}{l}\text { Francis, } \\
\text { W. P. }\end{array}$ & 2006 & Prosp. & $\begin{array}{l}\text { Newly diagnosed resectable breast } \\
\text { cancer patients }\end{array}$ & byears & 67.7 & $\begin{array}{l}\text { Arms circumference } \\
\text { measurements }\end{array}$ & USA & $\begin{array}{l}\text { Limb volume or circumferential } \\
\text { measurement increased by at least } 5 \%\end{array}$ \\
\hline $\begin{array}{l}\text { Goldberg, } \\
\text { J. I. }\end{array}$ & 2011 & Prosp. & $\begin{array}{l}\text { Women with clinically node-negative } \\
\text { breast cancer underwent SLNB }\end{array}$ & 4 years & 3 & $\begin{array}{l}\text { Arms circumference } \\
\text { measurements }\end{array}$ & USA & $\begin{array}{l}\text { Lymphoedema was defined as } L>2 \mathrm{~cm} \\
\text { for either the upper arm or the forearm }\end{array}$ \\
\hline $\begin{array}{l}\text { Goldberg, } \\
\text { J. I. }\end{array}$ & 2010 & Prosp. & $\begin{array}{l}\text { Women without history of breast } \\
\text { cancer or axillary surgery underwent } \\
\text { SLNB for clinically node-negative } \\
\text { breast cancer }\end{array}$ & 5 years & 5 & $\begin{array}{l}\text { Arms circumference } \\
\text { measurements }\end{array}$ & USA & $\begin{array}{l}\text { Lymphoedema was defined as } L>2 \mathrm{~cm} \\
\text { for either the upper arm or the forearm }\end{array}$ \\
\hline Mak, S. S. & 2008 & C.S. & $\begin{array}{l}\text { Patients with breast cancer undergone } \\
\text { unilateral axillary dissection }\end{array}$ & 17 months & 50 & $\begin{array}{l}\text { Arms Circumference } \\
\text { Measurements }\end{array}$ & $\begin{array}{l}\text { Hong } \\
\text { Kong }\end{array}$ & $\begin{array}{l}\text { Differences between } 2 \text { arm } \\
\text { circumferences at any level. }\end{array}$ \\
\hline $\begin{array}{l}\text { McLaughlin, } \\
\text { S. A. }\end{array}$ & 2013 & Prosp. & Women with ALND or SLNB & 20 months & 5 to 6 & Arms measurements & USA & $\begin{array}{l}\text { Ratio } \geq 1,10(10 \% \text { increase in the } \\
\text { ipsilateral arm when compared with } \\
\text { changes in the contralateral arm) }\end{array}$ \\
\hline $\begin{array}{l}\text { McLaughlin, } \\
\text { S. A. }\end{array}$ & 2008 & Prosp. & $\begin{array}{l}\text { Women underwent breast cancer } \\
\text { surgery with SLNB, without prior } \\
\text { axillary surgery, without history of } \\
\text { breast cancer, and had baseline } \\
\text { bilateral upper-extremity measurements }\end{array}$ & 5 years & 5 to 16 & $\begin{array}{l}\text { Arms circumference } \\
\text { measurements }\end{array}$ & USA & Lymphoedema $>2 \mathrm{~cm}$ for either location \\
\hline
\end{tabular}


FIGURE 2. Comparison of BMI Between Patients With and Without Lymphoedema

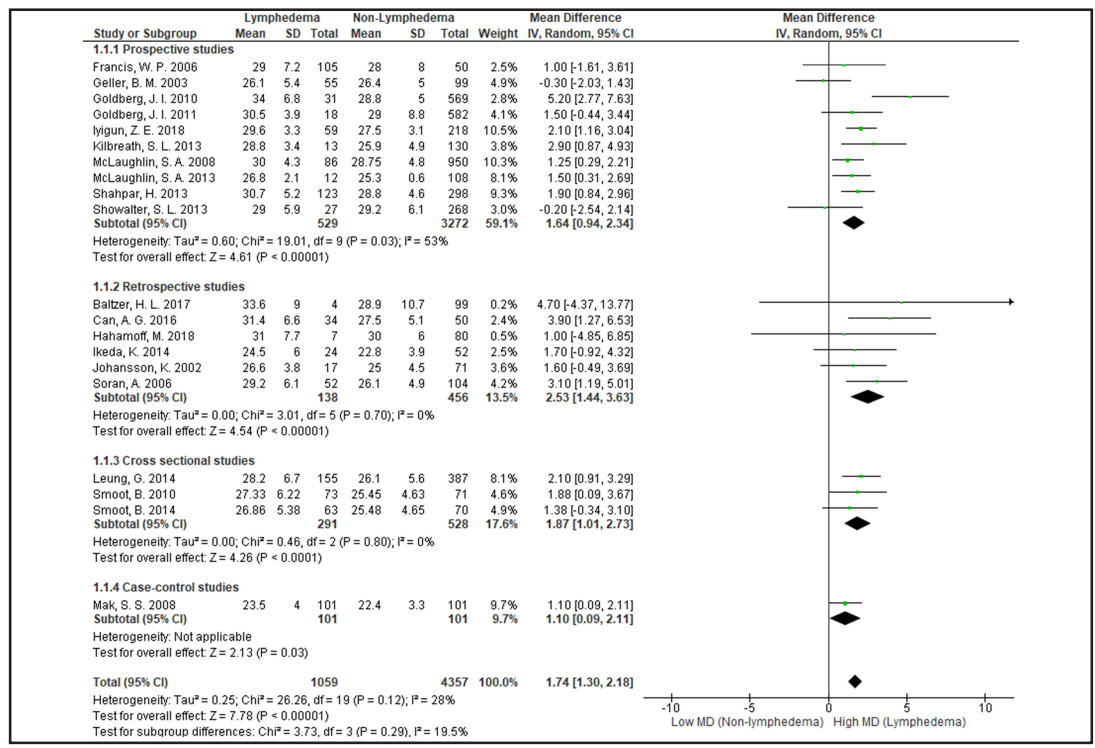

oedema. A random effects model, with a random intercept for each study, was developed to obtain pooled mean differences and ORs by study type. Study heterogeneity was assessed using the I2 index. I2>50\% with $P<.1$ indicated significant heterogeneity among studies. ${ }^{14}$ Subgroup analyses were performed to obtain OR and mean difference estimates according to the study design, notably, prospective, retrospective, cross-sectional and case-control studies. Review Manager version 5.3 (The Nordic Cochrane Centre, The Cochrane Collaboration, Copenhagen) was used for all statistical analyses.

\section{RESULTS}

\section{Study Characteristics}

We identified 2,911 studies through the MeSH search terms, of which 57 studies, published between 2002 and 2018, were included in the meta-analysis (Figure 1). Among them, 32 were prospective, ${ }^{15-46} 15$ were retrospective, ${ }^{47-61} 7$ were cross-sectional $^{62-68}$ and 3 were case-control. ${ }^{69-71}$ The included studies were conducted in USA (30), Korea (6), Turkey (4), China (3), Brazil (3), UK (2),Spain ( 1 ), Italy (1), Sweden (1), Romania (1), Japan ( 1), Australia ( 1 ), Hong Kong ( 1), Iran ( 1 ) and Jordan ( 1 ). Fourteen studies were classified as low quality and 43 were classified as high quality. The proportion of lymphoedema in prospective studies included in the meta-analysis ranged between $3 \%$ and $71.4 \%$ (Table). In total, 5,407 participants from 20 studies contributed data for analysis of mean differences in BMI between patients with and without lymphoedema. Overall, 23,208 participants from 38 studies contributed data for analyses of ORs associated with BMI category. Some of the 38 studies did not report on every category of BMI and thus were not included in every OR estimate, while other studies provided data for more than 1 OR estimate. Thus OR estimates of lymphoedema in patients with a $\mathrm{BMI}<25$ versus patients with a BMI $\geq 25$ included 33 studies; OR estimates of patients with a $\mathrm{BMI}<25$ versus patients with a $\mathrm{BMI} \geq 30$ included 20 studies; OR estimates of patients with a BMI $\geq 25$ to $<30$ versus patients with a $\mathrm{BMI} \geq 30$ included 20 studies; and OR estimates of patients with a $\mathrm{BMI}<25$ versus patients with a $\mathrm{BMI} \geq 25$ to $\mathrm{BMI}<30$ included 19 studies.

\section{Differences in BMI between Patients With and With- out Lymphoedema}

In meta-analysis of 20 studies the overall mean difference in BMI between breast cancer patients with and without lymphoedema was 1.7 (95\% confidence interval [CI], 1.3 to 2.2); heterogeneity among studies was nonsignificant (I2=28\%). In subgroup analysis by study design, in all study subgroups BMI was higher in breast cancer patients with lymphoedema compared to those without. However, the mean difference in BMI was higher in retrospective studies 2.5 (95\% CI, 1.4 to 3.6), compared to prospective 1.6 (95\% CI, 0.9 to 2.3 ), cross-sectional 1.9 (95\% CI, 1.0 to 2.7 ) and case-control studies 1.1 (95\% CI,0.1 to 2.1 ). Heterogeneity in prospective studies was moderate $(\mathrm{I} 2=53 \%)$ and nonsignificant $(\mathrm{I} 2=0 \%)$ in retrospective and cross-sectional studies.

\section{Odds of Lymphoedema by BMI Category}

Breast cancer patients with a BMI in the overweight or obese range more frequently developed lymphoedema than those with a $\mathrm{BMI}<25$, with risk rising across higher BMI categories. 
FIGURE 3. Forest Plot Comparing Lymphoedema in Patients With BMl $<25$ and Those With BMI $\geq 25$

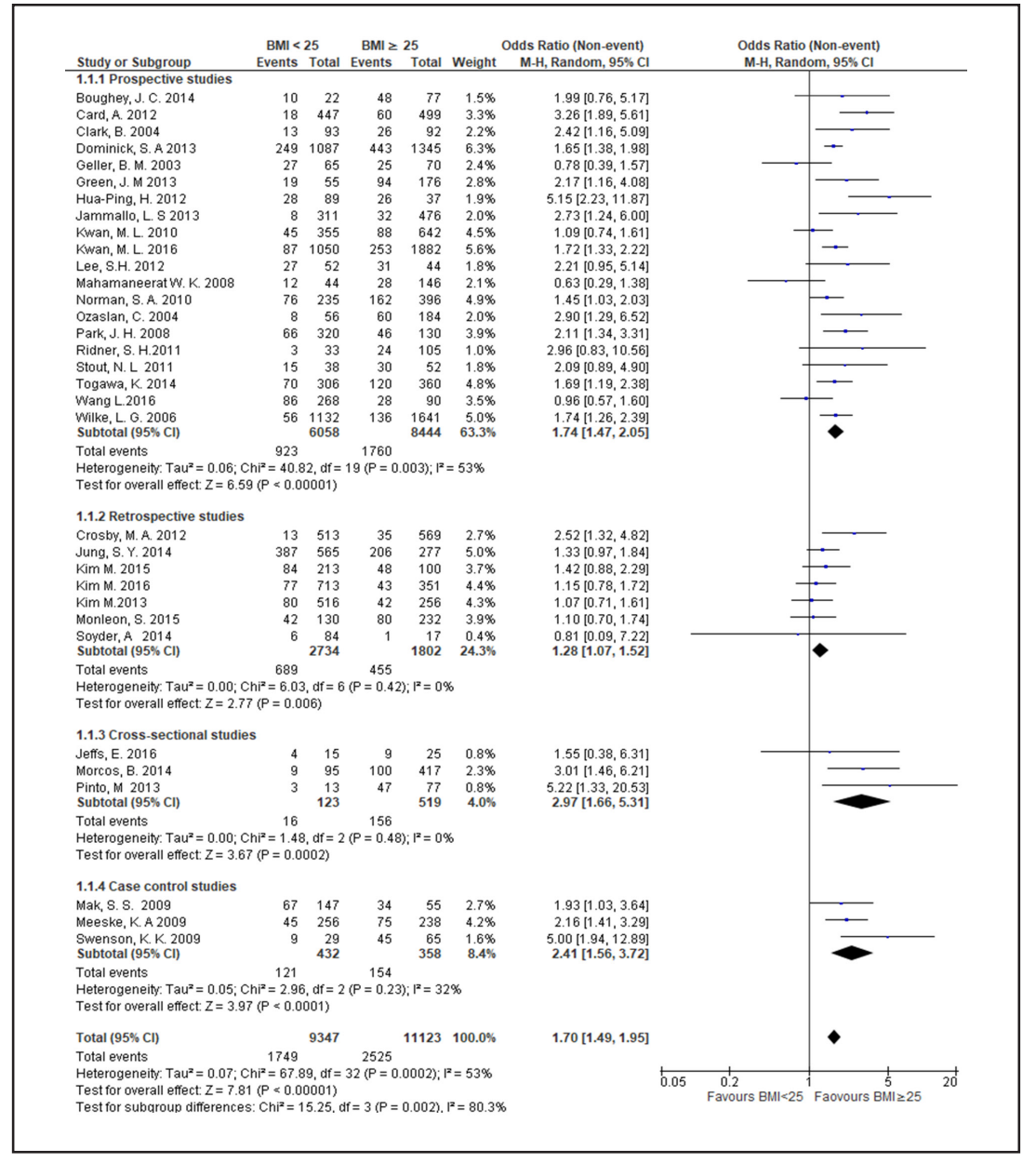

Compared to patients with a $\mathrm{BMI}<25$, risk of lymphoedema was higher in those with a BMI in range of 25 to less than 30 (odds ratio [OR] 1.3; 95\% CI, 1.2 to 1.5 ), a $\mathrm{BMI} \geq 25$ ( OR $1.7 ; 95 \% \mathrm{CI}, 1.5$ to 1.9 ), or a $\mathrm{BMI} \geq 30$ (OR $1.9 ; 95 \% \mathrm{CI}, 1.6$ to 2.4). Even among overweight or obese patients, higher BMI was associated with a greater frequency of lymphoedema. Compared to patients with a BMI between 25 and less than 30 , odds of lymphoedema was $50 \%$ higher patients with a $\mathrm{BMI} \geq 30$ (OR $1.5 ; 95 \%$ CI, 1.4 to 1.8 ).

Heterogeneity of OR estimates across studies was moderate in overall analyses comparing patients with $\mathrm{BMI}<25$ to those with $\mathrm{BMI} \geq 25(\mathrm{I} 2=53 \%)$ and comparing patients with $\mathrm{BMI}<25$ to those with $\mathrm{BMI}>30(\mathrm{I} 2=49 \%)$. Cross-study heterogenity was also moderate in subgroup analysis of prospective studies comparing patients with $\mathrm{BMI}<25$ to those with $\mathrm{BMI} \geq 25(\mathrm{I} 2=53 \%)$ and comparing patients with $\mathrm{BMI}<25$ to those with $\mathrm{BMI} \geq 30(\mathrm{I} 2=49 \%)$. Study heterogeneity was only substantial in subgroup analysis of cross-sectional studies comparing patients with BMI between 25 and 30 to those with $\mathrm{BMI} \geq 30(\mathrm{I} 2=75 \%)$. In all other analyses heterogeneity was nonsignificant.

In subgroup analyses based on study design comparing patients with a $\mathrm{BMI}<25$ to patients with a $\mathrm{BMI} \geq 25$, mean ORs were higher in cross-sectional studies (OR 2.9; 95\% CI, 1.7 to 5.3 ) and case-control studies (OR 2.4; $95 \%$ CI, 1.6 to 3.7 ) compared to prospective studies (OR $1.7 ; 95 \% \mathrm{CI}, 1.5$ to 2.1 ), and retrospective studies (OR 1.3; 95\% CI, 1.1 to 1.5 ). In contrast, in subgroup analyses comparing patients with a BMI of 25 to less than 30 to patients with a $\mathrm{BMI} \geq 30$, the mean OR was higher in prospective studies (OR 1.6; 95\% CI, 1.4 to 1.8 ) compared to retrospective studies (OR 1.3; 95\% CI, 0.8 to 1.9 ) and cross-sectional studies (OR 1.2; 95\% CI, 0.1 to 13.6).In subgroup analyses comparing patients with a $\mathrm{BMI}<25$ to patients with a $\mathrm{BMI} \geq 30$, mean ORs by study types ranged from 1.9 to 2.5 in cross-prospective, cross-sectional and case control studies, with an overall OR of near 2 (OR 1.9; 95\% CI, 1.6 to 


\section{FIGURE 4. Forest Plot Comparing Lymphoedema in Patients With BMI $<25$ and Those With BMI $\geq 30$}

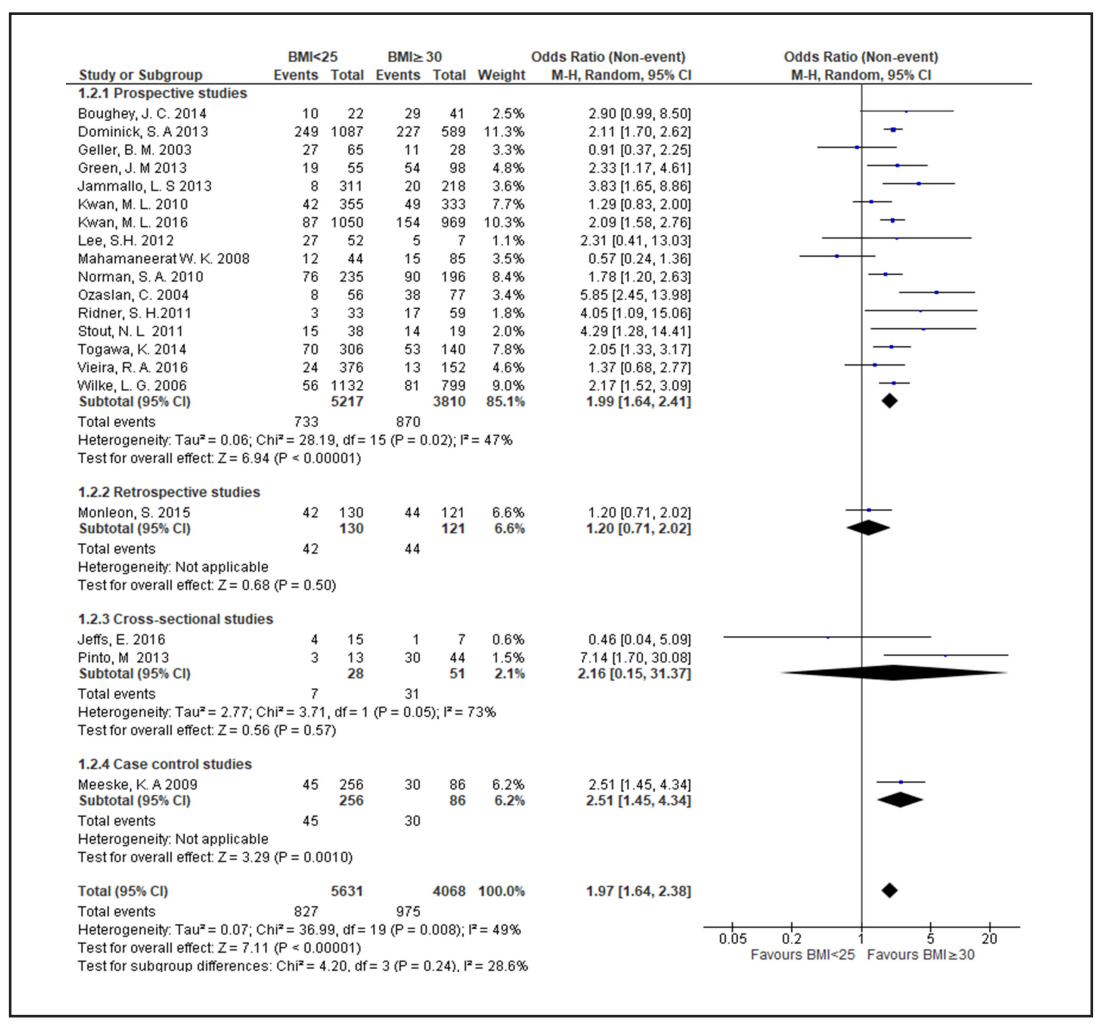

2.4) (Figure 4). A wider range of mean ORs was observed in subgroup analyses comparing patients with a $\mathrm{BMI}<25$ to patients with a $\mathrm{BMI} \geq 25$ and less than 30 . The OR was lowest in the retrospective study subgroup, which represented a single study (OR 1; 95\% CI, 0.6 to 1.7 ), moderate in the prospective study subgroup (OR 1.3; 95\% CI, 1.2 to 1.5 ), and highest in the cross-sectional study subgroup (OR 1.9; 95\% CI, 0.7 to 5.5) and the case-control study subgroup (OR 1.9; 95\% CI, 1.2 to 3.2), which also represented a single study (Figure 6).

\section{DISCUSSION}

In this meta-analysis, we found strong associations between BMI and lymphoedema in female breast cancer patients. Mean differences in BMI were significantly elevated in lymphoedema patients compared with those who did not develop lymphoedema. Further, compared to a reference BMI value of $<25$ (that is, at or below normal weight), ORs for lymphoedema increased in magnitude across higher categories of BMI, within the range of 1.3 to 1.9. This finding reflects a trend of increasing risk of lymphoedema with increasing weight reported in individual studies included in this meta-analysis. While ORs of the association of BMI category and lymphoedema from individual studies ranged from $0.3^{62}$ to $7.1,^{64}$ only 5 studies reported an OR below 1 , reflecting the robustness of our overall estimate. Further, study heterogeneity was moderate to nonsignificant in most analyses and $75 \%$ of included studies were of high quality. We observed some variability in the magnitude of ORs by subgroup of study design type, however, subgroup ORs were largely consistent with overall ORs.

Strikingly, we found that even among overweight and obese cancer patients, higher BMI increased risk of lymphoedema. In particular, our analysis estimated that risk of lymphoedema was $50 \%$ higher in patients with a BMI>30 compared to those with a BMI in the range of 25 to less than 30. This finding is supported by a recent meta-analysis of BMI and risk of lymphoedema, which reported an 39\% increased risk of breast cancer-related lymphoedema in obese patients compared to overweight patients. ${ }^{81}$ However, lymphoedema is more noticeable, and thus potentially more readily diagnosed in patients with a high BMI compared to those with a normal BMI. While the contribution of diagnostic bias to the observed association between higher BMI and increased risk of lymphoedema is unknown, the observed dose-response relationship between excess body weight and increased risk of lymphoedema suggests a biological link between the 2 .

In prospective studies that were included in this meta-analysis, we found a high proportion of lymphoedema, 
FIGURE 5. Forest Plot Comparing Lymphoedema in Patients With $25 \leq \mathrm{BMl}<30$ and Those With $\mathrm{BMI} \geq 30$

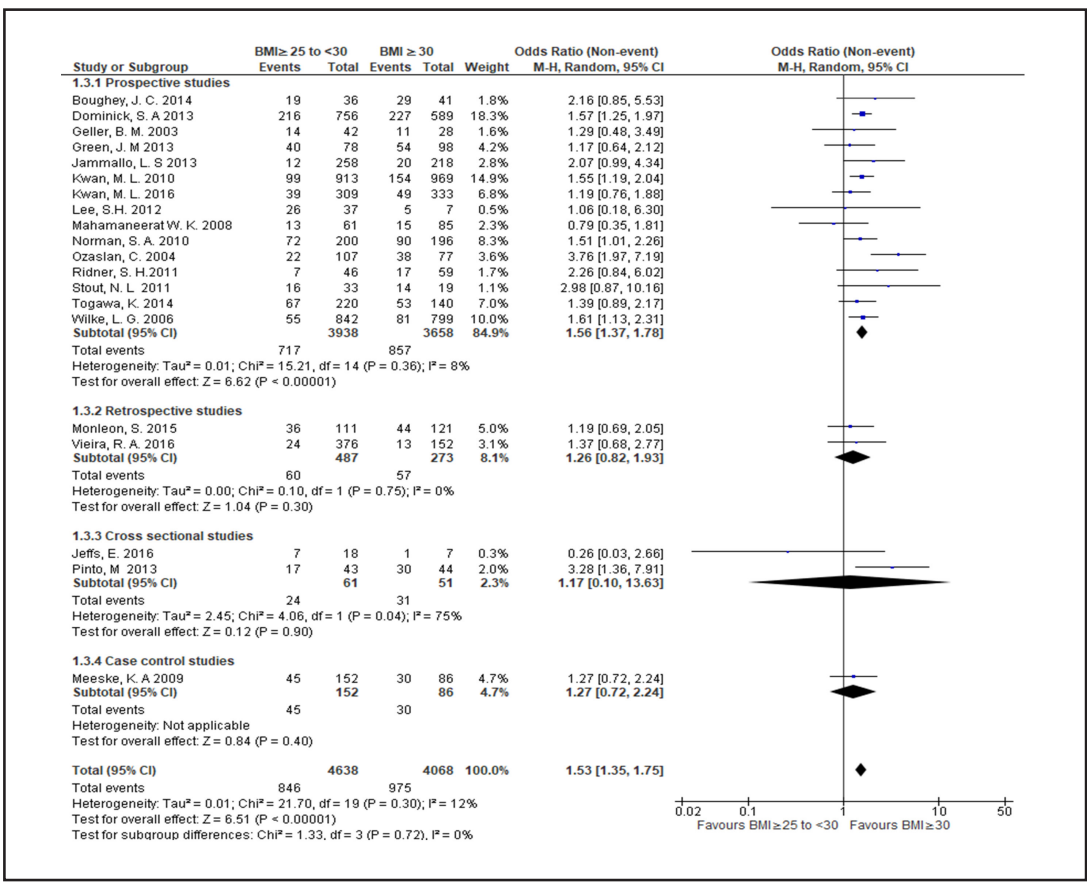

FIGURE 6. Forest Plot Comparing Lymphoedema in Patients With BMI $<25$ and Those With $25 \leq \mathrm{BMI}<30$

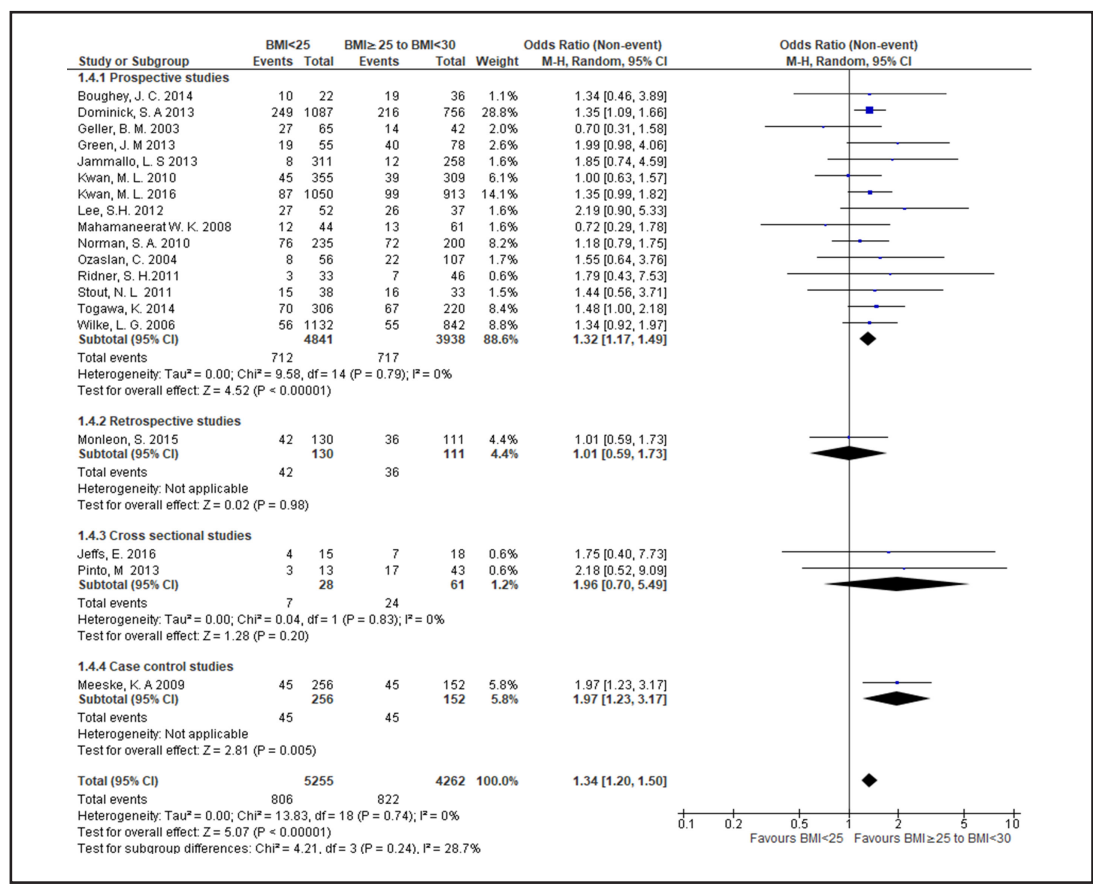




\section{FIGURE 7. Funnel Plots Referring to Previous Figures}

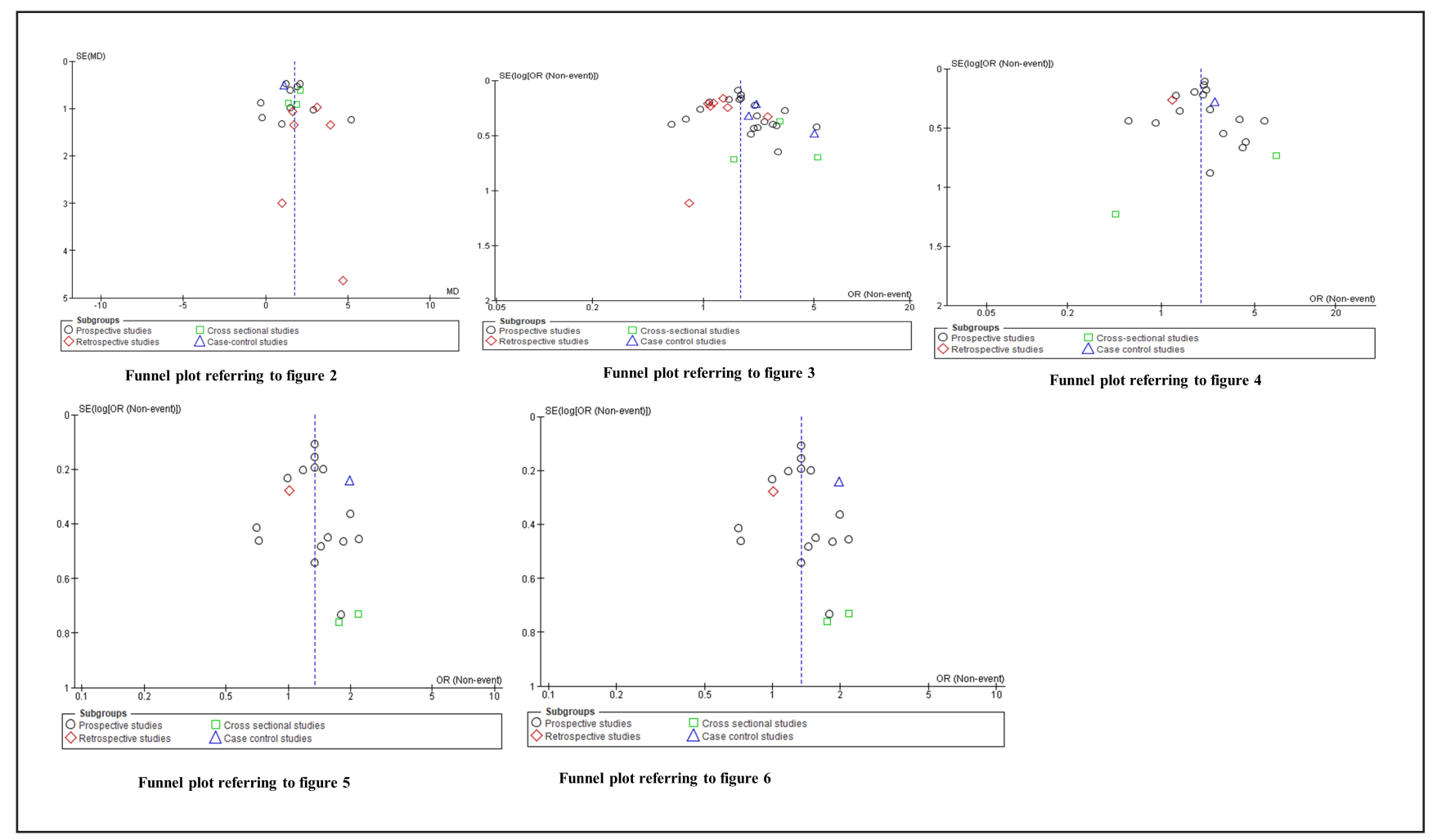

ranging from $3 \%$ to $67.7 \%$, with a mean of $24.19 \%$. A similarly high proportion of lymphoedema has been reported in other studies. Based on insurance claim data, 10\% of patients had lymphoedema within 2 years of treatment of newly diagnosed breast cancer. ${ }^{85}$ A prospective cohort study of breast cancer survivors reported that within 5 years of treatment $43 \%$ to $94 \%$ of patients had lymphoedema, with estimates varying depending upon how the lymphoedema was defined. ${ }^{86}$ These incidence estimates are derived from overall patient populations, and may be even higher in subgroups of overweight and obese women in whom risk of lymphoedema is elevated.

The process through which higher BMI may lead to the development of lymphoedema remains unclear but several mechanisms have been proposed. In particular, lipid accumulation throughout the body may impede lymphatic transport of fluids, in a process driven in part by chronic inflammatory responses. ${ }^{82}$ In a mouse model, lymphoedema in obese mice was found to impair lymphatic function, associated with increased subcutaneous adipose deposition, a higher frequency of CD45+ and CD4+ inflammatory cells, and fibrosis without any change in the number of lymphatic vessels. $^{83}$

\section{Limitations}

Our meta-analysis has some limitations, which should be considered. Firstly, methods used to diagnose lymphoedema were not consistent across the studies included in this meta-analysis, and some studies did report on how diagnosis was conducted. In some studies, BMI was not a primary variable of interest, and thus may not have been carefully recorded. Further, a variety of study populations were represented across studies, including. While this may improve the overall generalizability of our findings, it may also have resulted in wider confidence intervals around our pooled estimates. Our study did not include 191 non-English citations identified by our MeSH search, which could contain important data not considered in this study. Moreover, the majority of studies included in our meta-analysis were conducted in the USA $(52.3 \%)$ or in Europe, thus our results may not reflect the impact of BMI on risk of lymphoedema in geographic areas not included in the analysis. The publication biases assessment has been summarised in Figure 7 by using funnel plots. The significant asymmetry was found in the funnel plots referring to Figure 3. This should be caused by heterogeneity within studies. 


\section{CONCLUSION}

This meta-analysis showed that being overweight or obese is an important risk factor for developing lymphoedema of the upper limb following breast cancer treatment. Lymphoede$\mathrm{ma}$ is more noticeable, and thus potentially more readily diagnosed in patients with a high BMI compared to those with a normal BMI. However, our finding that the magnitude of risk of lymphoedeoma rises across higher categories of BMI supports a biological link between being overweight and developing lymphoedeoma. To further clarify the relationship between excess body weight and risk of lymphoedema, future studies should detail methods used to diagnose lymphoedema and report the frequency of lymphoedema in BMI subgroups from patient populations representing a range of BMI levels.

Acknowledgements: We thank Mr Venuste Niyongabo for his contributions in English correction

\section{REFERENCES}

1. Williams AF, Franks PJ, Moffatt CJ. Lymphoedema: estimating the size of the problem. Palliat Med. 2005;19(4):300-313. CrossRef. Medline

2. Ridner SH. Breast cancer lymphedema: pathophysiology and risk reduction guidelines. Oncol Nurs Forum. 2002;29(9):1285-1293. CrossRef. Medline

3. Ben Salah H, Bahri M, Jbali B, Guermazi M, Frikha M, Daoud J. [Upper limb lymphedema after breast cancer treatment]. Cancer Radiother. 2012;16(2):123-127. CrossRef. Medline

4. Merchant SJ, Chen SL. Prevention and management of lymphedema after breast cancer treatment. Breast J. 2015;21(3):276-284. CrossRef. Medline

5. Vignes $S$, Arrault $M$, Dupuy A. Factors associated with increased breast cancer-related lymphedema volume. Acta Oncol. 2007;46(8): $1138-1142$ CrossRef. Medline

6. Degnim AC, Miller J, Hoskin TL, et al. A prospective study of breast lymphedema: frequency, symptoms, and quality of life. Breast Cancer Res Treat. 2012;134(3):915-922. CrossRef. Medline

7. Lopez Penha TR, Slangen JJ, Heuts EM, Voogd AC, Von Meyenfeldt MF. Preva lence of lymphoedema more than five years after breast cancer treatment. Eur J Surg Oncol. 2011;37(12):1059-1063. CrossRef. Medline

8. Arrault $M$, Vignes $S$. [Risk factors for developing upper limb lymphedema after breast cancer treatment]. Bull Cancer. 2006;93(10):1001-1006. Medline

9. DiSipio T, Rye S, Newman B, Hayes S. Incidence of unilateral arm lymphoedema after breast cancer: a systematic review and meta-analysis. Lancet Oncol. 2013;14(6):500-515. CrossRef. Medline

10. Ozcinar B, Guler SA, Kocaman N, Ozkan M, Gulluoglu BM, Ozmen V. Breas cancer related lymphedema in patients with different loco-regional treatments. Breast. 2012;21(3):361-365. CrossRef. Medline

11. Tsai RJ, Dennis LK, Lynch CF, Snetselaar LG, Zamba GK, Scott-Conner C. The risk of developing arm lymphedema among breast cancer survivors: a meta-analysis of treatment factors. Ann Surg Oncol. 2009;16(7):1959-1972. CrossRef. Medline

12. Wan X, Wang W, Liu J, Tong T. Estimating the sample mean and standard deviation from the sample size, median, range and/or interquartile range. BMC Med Res Methodol. 2014;14:135. CrossRef. Medline

13. National Heart, Lung, and Blood Institute (NHLBI). Study quality assessment tools. NHLBI Website. https://www.nhlbi.nih.gov/health-topics/study-quality-assessment-tools.

14. Higgins JPT, Thomas J, Chandler J, et al (editors). Cochrane Handbook for Systematic Reviews of Interventions version 6.0 (updated July 2019). Cochrane: 2019. www.training.cochrane.org/handbook

15. Boughey JC, Hoskin TL, Cheville AL, et al. Risk factors associated with breas lymphedema. Ann Surg Oncol. 2014;21(4):1202-1208. CrossRef. Medline

16. Card A, Crosby MA, Liu J, Lindstrom WA, Lucci A, Chang DW. Reduced incidence of breast cancer-related lymphedema following mastectomy and breast reconstruction versus mastectomy alone. Plast Reconstr Surg 2012;130(6):1169-1178. CrossRef. Medline

17. Clark B, Sitzia J, Harlow W. Incidence and risk of arm oedema following treatment for breast cancer: a three-year follow-up study. QJM. 2005 My;98(5):343-348. CrossRef. Medline

18. Dominick SA, Madlensky L, Natarajan L, Pierce JP. Risk factors associated with breast cancer-related lymphedema in the WHEL Study. J Cancer Surviv. 2013;7(1):115-123. CrossRef. Medline

19. Geller BM, Vacek PM, O'Brien P, Secker-Walker RH. Factors associated with arm swelling after breast cancer surgery. J Womens Health (Larchmt). 2003;12(9):921-930. CrossRef. Medline

20. Green JM, Paladugu S, Shuyu X, Stewart BR, Shyu CR, Armer JM. Using temporal mining to examine the development of lymphedema in breast cancer survivors. Nurs Res. 2013;62(2):122-129. CrossRef. Medline

21. Hua-Ping $H$, Jian-Rong $Z$, Zeng $Q$. Risk factors associated with lymphedema among postmenopausal breast cancer survivors after radical mastectomy and axillary dissection in China. Breast Care (Basel). 2012;7(6):461-464. CrossRef. Medline

22. Jammallo $L S$, Miller $C L$, Singer $M$, et al. Impact of body mass index and weight fluctuation on lymphedema risk in patients treated for breast cancer. Breast Cancer Res Treat. 2013;142(1):59-67. CrossRef. Medline

23. Kwan ML, Darbinian J, Schmitz KH, et al. Risk factors for lymphedema in a prospective breast cancer survivorship study: the Pathways Study. Arch Surg. 2010;145(1 1):1055-1063. CrossRef. Medline

24. Kwan ML, Yao S, Lee VS, et al. Race/ethnicity, genetic ancestry, and breast cancer-related lymphedema in the Pathways Study. Breast Cancer Res Treat. 2016;159(1):119-129. CrossRef. Medline

25. Lee SH, Min YS, Park HY, Jung TD. Health-related quality of life in breast cancer patients with lymphedema who survived more than one year after surgery. $J$ Breast Cancer. 2012;15(4):449-453. CrossRef. Medline

26. Mahamaneerat WK, Shyu CR, Stewart BR, Armer JM. Breast cancer treatment, BMI, post-op swelling/lymphoedema. J Lymphoedema. 2008;3(2):38-44. Medline

27. Menezes MM, Bello MA, Millen E, et al. Breast reconstruction and risk of lymphedema after mastectomy: A prospective cohort study with 10 years of follow-up. J Plast Reconstr Aesthet Surg. 2016;69(9):1218-1226. CrossRef. Medline

28. Norman SA, Localio AR, Kallan MJ, et al. Risk factors for lymphedema after breast cancer treatment. Cancer Epidemiol Biomarkers Prev. 2010;19(11):2734-2746. CrossRef. Medline

29. Ozaslan C, Kuru B. Lymphedema after treatment of breast cancer. Am J Surg. 2004;187(1):69-72. CrossRef. Medline

30. Park JH, Lee WH, Chung HS. Incidence and risk factors of breast cancer lymphoedema. J Clin Nurs. 2008;17(11):1450-1459. CrossRef. Medline

31. Rebegea L, Firescu D, Dumitru M, Anghel R. The incidence and risk factors for occurrence of arm lymphedema after treatment of breast cancer. Chirurgia (Bucur). 2015;110(1):33-37. Medline

32. Ribeiro Pereira ACP, Koifman RJ, Bergmann A. Incidence and risk factors of lymphedema after breast cancer treatment: 10 years of follow-up. Breast. 2017;36:67-73. CrossRef. Medline

33. Ridner SH, Dietrich MS, Stewart BR, Armer JM. Body mass index and breast cancer treatment-related lymphedema. Support Care Cancer. 2011 Jun; 19(6):853-857. CrossRef. Medline

34. Stout NL, Pfalzer LA, Levy E, et al. Segmental limb volume change as a predictor of the onset of lymphedema in women with early breast cancer. PM $R$ 2011;3(12):1098-1105. CrossRef. Medline

35. Togawa K, Ma H, Sullivan-Halley J, et al. Risk factors for self-reported arm lymphedema among female breast cancer survivors: a prospective cohort study. Breast Cancer Res. 2014;16(4):414. CrossRef. Medline

36. Wang L, Li HP, Liu AN, et al. A scoring system to predict arm lymphedema risk for individual Chinese breast cancer patients. Breast Care (Basel) 2016;11(1):52-56. CrossRef. Medline

37. Wilke LG, McCall LM, Posther KE, et al. Surgical complications associated with sentinel lymph node biopsy: results from a prospective international cooperative group trial. Ann Surg Oncol. 2006;13(4):491-500. CrossRef. Medline

38. Francis WP, Abghari P, Du W, Rymal C, Suna M, Kosir MA. Improving surgical 
outcomes: standardizing the reporting of incidence and severity of acute lymphedema after sentinel lymph node biopsy and axillary lymph node dissection. Am J Surg. 2006;192(5):636-639. CrossRef. Medline

39. Goldberg Jl, Wiechmann LI, Riedel ER, Morrow M, Van Zee KJ. Morbidity of sentinel node biopsy in breast cancer: the relationship between the number of excised lymph nodes and lymphedema. Ann Surg Oncol. 2010;17(12):32783286. CrossRef. Medline

40. Goldberg J, Riedel ER, Morrow M, Van Zee KJ. Morbidity of sentinel node biopsy: relationship between number of excised lymph nodes and patient perceptions of lymphedema. Ann Surg Oncol. 2011;18(10):2866-2872. CrossRef. Medline

41. Ilyigun ZE, Duymaz T, Ilgun AS. Preoperative lymphedema-related risk factors in early-stage breast cancer. Lymphat Res Biol. 2018;16(1):28-35. CrossRef. Medline

42. Kilbreath SL, Lee MJ, Refshauge KM, et al. Transient swelling versus lymphoedema in the first year following surgery for breast cancer. Support Care Cancer. 2013;21(8):2207-2215. CrossRef. Medline

43. McLaughlin SA, Bagaria S, Gibson T, et al. Trends in risk reduction practices for the prevention of lymphedema in the first 12 months after breast cancer surgery. J Am Coll Surg. 2013;216(3):380-389. CrossRef. Medline

44. Shahpar H, Atieh A, Maryam A, et al. Risk factors of lymph edema in breast cancer patients. Int J Breast Cancer. 2013;2013:641818. CrossRef. Medline

45. Showalter SL, Brown JC, Cheville AL, Fisher CS, Sataloff D, Schmitz KH. Lifestyle risk factors associated with arm swelling among women with breast cancer. Ann Surg Oncol. 2013;20(3):842-849. CrossRef. Medline

46. McLaughlin SA, Wright MJ, Morris KT. Prevalence of lymphedema in women with breast cancer 5 years after sentinel lymph node biopsy or axillary dissection: patient perceptions and precautionary behaviors. J Clin Oncol. 2008;26(32):5220-5226. CrossRef. Medline

47. Crosby MA, Card A, Liu J, Lindstrom WA, Chang DW. Immediate breast reconstruction and lymphedema incidence. Plast Reconstr Surg 2012;129(5):789e-795e. CrossRef. Medline

48. Hinrichs CS, Watroba NL, Rezaishiraz H, et al. Lymphedema secondary to postmastectomy radiation: incidence and risk factors. Ann Surg Oncol. 2004; 1 1(6):573-580. CrossRef. Medline

49. Jung SY, Shin KH, Kim M, et al. Treatment factors affecting breast cancer-related lymphedema after systemic chemotherapy and radiotherapy in stage II/III breast cancer patients. Breast Cancer Res Treat. 2014;148(1):91-98. CrossRef. Medline

50. Kim M, Kim SW, Lee SU, et al. A model to estimate the risk of breast cancer-related lymphedema: combinations of treatment-related factors of the number of dissected axillary nodes, adjuvant chemotherapy, and radiation therapy. Int J Radiat Oncol Biol Phys. 2013;86(3):498-503. CrossRef. Medline

51. Kim M, Park IH, Lee KS. Breast cancer-related lymphedema after neoadjuvant chemotherapy. Cancer Res Treat. 2015;47(3):416-423. CrossRef. Medline

52. Kim M, Shin $\mathrm{KH}$, Jung SY, et al. Identification of prognostic risk factors for transient and persistent lymphedema after multimodal treatment for breast cancer. Cancer Res Treat. 2016;48(4):1330-1337. CrossRef. Medline

53. Monleon S, Murta-Nascimento C, Bascuas I, Macià F, Duarte E, Belmonte R. Lymphedema predictor factors after breast cancer surgery: a survival analysis. Lymphat Res Biol. 2015;13(4):268-274. CrossRef. Medline

54. Soyder A, Taştaban E, Özbaş S, Boylu Ş, Özgün H. Frequency of early-stage lymphedema and risk factors in postoperative patients with breast cancer. $J$ Breast Health. 2014;10(2):92-97. CrossRef. Medline

55. Vieira RA, da Costa AM, de Souza JL, et al. Risk factors for arm lymphedema in a cohort of breast cancer patients followed up for 10 Years. Breast Care (Basel). 2016;11(1):45-50. CrossRef. Medline

56. Baltzer HL, Harvey J, Fox PM, Moran SL. De novo upper extremity lymphedema after elective hand surgery in breast cancer survivors. Ann Plast Surg. 2017;79(1):24-27. CrossRef. Medline

57. Can AG, Ekşioğlu E, Bahtiyarca ZT, Çakcı FA. Assessment of risk factors in patients who presented to the outpatient clinic for breast cancer-related lymphedema. J Breast Health. 2016;12(1):31-36. CrossRef. Medline

58. Hahamoff M, Gupta N, Munoz D, et al. A lymphedema surveillance program for breast cancer patients reveals the promise of surgical prevention. J Surg Res. 2019;244:604-611. CrossRef. Medline

59. Ikeda K, Ogawa Y, Kajino C, et al. The influence of axillary reverse mapping related factors on lymphedema in breast cancer patients. Eur J Surg Oncol. 2014;40(7):818-823. CrossRef. Medline

60. Johansson K, Ohlsson K, Ingvar C, Albertsson M, Ekdahl C. Factors associated with the development of arm lymphedema following breast cancer treatment: a match pair case-control study. Lymphology. 2002;35(2):59-71. Medline

61. Soran A, D'Angelo G, Begovic $M$, et al. Breast cancer-related lymphedema--what are the significant predictors and how they affect the severity of lymphedema?. Breast J. 2006;12(6):536-543. CrossRef. Medline

62. Jeffs $E$, Purushotham A. The prevalence of lymphoedema in women who attended an information and exercise class to reduce the risk of breast cancer-related upper limb lymphoedema. Springerplus. 2016;5:21. CrossRef. Medline

63. Morcos B, Ahmad FA, Anabtawi I, Sba' AM, Shabani H, Yaseen R. Development of breast cancer-related lymphedema: is it dependent on the patient, the tumor or the treating physicians?. Surg Today. 2014;44(1):100-106. CrossRef. Medline

64. Pinto M, Gimigliano F, Tatangelo F, et al. Upper limb function and quality of life in breast cancer related lymphedema: a cross-sectional study. Eur J Phys Rehabil Med. 2013;49(5):665-673. Medline

65. Leung G, Baggott C, West C, et al. Cytokine candidate genes predict the development of secondary lymphedema following breast cancer surgery. Lymphat Res Biol. 2014;12(1):10-22. CrossRef. Medline

66. Mak SS, Yeo W, Lee YM, et al. Predictors of lymphedema in patients with breast cancer undergoing axillary lymph node dissection in Hong Kong. Nurs Res. 2008;57(6):416-425. CrossRef. Medline

67. Smoot B, Wong J, Cooper B. Upper extremity impairments in women with or without lymphedema following breast cancer treatment. J Cancer Surviv. 2010;4(2):167-178. CrossRef. Medline

68. Smoot B, Zerzan S, Krasnoff J, Wong J, Cho M, Dodd M. Upper extremity bioimpedance before and after treadmill testing in women post breast cancer treatment. Breast Cancer Res Treat. 2014;148(2):445-453. CrossRef. Medline

69. Meeske KA, Sullivan-Halley J, Smith AW, et al. Risk factors for arm lymphedema following breast cancer diagnosis in Black women and White women. Breast Cancer Res Treat. 2009;113(2):383-391. CrossRef. Medline

70. Mak SS, Mo KF, Suen JJ, Chan SL, Ma WL, Yeo W. Lymphedema and quality of life in Chinese women after treatment for breast cancer. Eur J Oncol Nurs. 2009;13(2):1 10-115. CrossRef. Medline

71. Swenson KK, Nissen MJ, Leach JW, Post-White J. Case-control study to evaluate predictors of lymphedema after breast cancer surgery. Oncol Nurs Forum. 2009;36(2):185-193. CrossRef. Medline

72. Hayes SC, Janda M, Cornish B, Battistutta D, Newman B. Lymphedema after breast cancer: incidence, risk factors, and effect on upper body function. J Clin Oncol. 2008;26(21):3536-3542. CrossRef. Medline

73. Honarvar B, Sayar N, Tahmasebi S, et al. Correlates of lymphedema in women with breast cancer: a case control study in Shiraz, Southern Iran. Asian Pac J Cancer Prev. 2016;17(S3):81-86. CrossRef. Medline

74. Huang HP, Zeng Q, Zhou JR. Risk factors associated with lymphoedema among Chinese women after breast cancer surgery. Contemp Nurse. 2013;44(1):5-10. CrossRef. Medline

75. Nielsen I, Gordon S, Selby A. Breast cancer-related lymphoedema risk reduction advice: a challenge for health professionals. Cancer Treat Rev. 2008;34(7):621-628. CrossRef. Medline

76. Basta MN, Fischer JP, Kanchwala SK, et al. A Propensity-matched analysis of the influence of breast reconstruction on subsequent development of lymphedema. Plast Reconstr Surg. 2015;136(2):134e-143e. CrossRef. Medline

77. Clough-Gorr KM, Ganz PA, Silliman RA. Older breast cancer survivors: factors associated with self-reported symptoms of persistent lymphedema over 7 years of follow-up. Breast J. 2010;16(2):147-155. CrossRef. Medline

78. Kilbreath SL, Refshauge KM, Beith JM, et al. Risk factors for lymphoedema in women with breast cancer: a large prospective cohort. Breast. 2016;28:2936. CrossRef. Medline

79. Paskett ED, Naughton MJ, McCoy TP, Case LD, Abbott JM. The epidemiology of arm and hand swelling in premenopausal breast cancer survivors. Cancer Epidemiol Biomarkers Prev. 2007;16(4):775-782. CrossRef. Medline

80. Mehrara BJ, Greene AK. Lymphedema and obesity: is there a link?. Plast Reconstr Surg. 2014;134(1):154e-160e. CrossRef. Medline

81. Wu R, Huang $X$, Dong $X$, Zhang $H$, Zhuang L. Obese patients have higher risk 
of breast cancer-related lymphedema than overweight patients after breast cancer: a meta-analysis. Ann Transl Med. 2019;7(8):172. CrossRef. Medline

82. Rutkowski JM, Davis KE, Scherer PE. Mechanisms of obesity and related pathologies: the macro- and microcirculation of adipose tissue. FEBS J. 2009;276(20):5738-5746. CrossRef. Medline

83. Savetsky IL, Torrisi JS, Cuzzone DA, et al. Obesity increases inflammation and impairs lymphatic function in a mouse model of lymphedema. Am J Physiol Heart Circ Physiol. 2014;307(2):H165-172. CrossRef. Medline

84. Ferrandez JC, Serin D, Bouges S. [Frequency of lymphedema of the upper limb after treatment of breast cancer. Risk factors. Apropos of 683 cases]. Bull Cancer. 1996;83(12):989-995. Medline

85. Shih $Y C, X \cup Y$, Cormier JN, et al. Incidence, treatment costs, and complications of lymphedema after breast cancer among women of working age: a 2-year follow-up study. J Clin Oncol. 2009;27(12):2007-2014. CrossRef. Medline

86. Armer JM, Stewart BR. Post-breast cancer lymphedema: incidence increases from 12 to 30 to 60 months. Lymphology. 2010;43(3):118-127. Medline

\section{Peer Reviewed}

Competing Interests: None declared.

Received: 3 Dec 2018; Accepted: 7 Oct 2019

Cite this article as: Manirakiza A, Irakoze L, Shui L, Manirakiza S, Ngendahayo L. Lymphoedema After Breast Cancer Treatment is Associated With Higher Body Mass Index: A Systematic Review and Meta-Analysis. East Afr Health Res J. 2019;3(2):178-192. http://doi.org/10.24248/EAHRJ-D-19-00009.

(c) Manirakiza et al. This is an open-access article distributed under the terms of the Creative Commons Attribution License, which permits unrestricted use, distribution, and reproduction in any medium, provided the original author and source are properly cited. To view a copy of the license, visit http://creativecommons.org/licenses/ by/4.0/. When linking to this article, please use the following permanent link: http:// doi.org/10.24248/EAHRJ-D-19-00009. 